\title{
EFFECT OF PARTICLE IMPINGEMENT ON ELECTROCHEMICAL PROPERTIES OF STAINLESS STEEL IN A JET FLOW
}

\author{
VPLIV TRKOV DELCEV V REAKTIVNEM TOKU NA \\ ELEKTROKEMIJSKE LASTNOSTI NERJAVNEGA JEKLA
}

\author{
Jiarui Cheng', Ningsheng Zhang',2, Yihua ${ }^{1}{ }^{3}{ }^{3}$, Zhen $\mathrm{Li}^{3}$, Yinping $\mathrm{Cao}^{3}$ \\ ${ }^{1}$ Xi' an Jiaotong University, State Key Laboratory of Multiphase Flow in Power Engineering, 28 Xianning West Road, Xi' an City, Shaanxi \\ Province 710049 , China \\ ${ }^{2} X i$ ' an Shiyou, University, Department of Petroleum Engineering, 18, Dianzi $2^{\text {nd }}$ Road, Xi' an City, Shaanxi Province 710065, China \\ ${ }^{3} X i$ ' an Shiyou University, Department of Mechanical Engineering, Xi' an City, Shaanxi Province 710065, China \\ cjr88112@163.com
}

Prejem rokopisa - received: 2017-06-21; sprejem za objavo - accepted for publication: 2017-12-21

doi:10.17222/mit.2017.079

\begin{abstract}
The objective of this research was to discuss the effects of physical impingement on the corrosion resistance of super $13 \mathrm{Cr}$ stainless steel in a solid-liquid jet flow. Data from standard laboratory tests including open-circuit potential (OCP), polarization potential, current and surface morphology was obtained. In addition, the passivation process at a changing flow velocity and after particle impacts were discussed using a point-defect model (PDM). The experimental results showed that particle impacts affect not only the electrochemical parameters but also the apparent structure of a sample, thus weakening the surface corrosion resistance of stainless steel. An uninterrupted particle impact damages loose passive films, decreases the electric potential and increases the current density. When the change in the potential reaches a stable state, the metal potential is gradually increased due to the influence of passivation; the passivation rate is the most significant at the beginning of the passivation and at a low flow velocity.

Keywords: solid-liquid two-phase flow, electrochemical property, passive film, repassivation
\end{abstract}

Predmet raziskave je bil raziskati vplive fizikalnih trkov na odpornost proti koroziji super nerjavnega jekla $13 \mathrm{Cr}$ v toku mešanice kapljevine in trdne faze. Avtorji so podatke zbrali s pomočjo standardnih laboratorijskih testov, kot so: potencial v odprtem tokokrogu (OCP; angl.: open-circuit potential), površinska morfologija, polarizacijski potencial in tok. Dodatno so uporabili model točkovnih napak (PDM; angl.: Point Defect Model) za razlago procesa pasivacije v spreminjajočih se pogojih hitrosti pretoka medija po trkanju delcev na površino vzorca. Rezultati preizkusov so pokazali, da trki delcev ne vplivajo samo na elektrokemične procese temveč tudi na navidezno strukturo vzorca in s tem se slabi protikorozijska odpornost nerjavnega jekla. Neprekinjeno mesebojno trkanje (udarjanje oz. zadevanje) delcev poškoduje pasivni film in tako zmanjša električni potencial ter poveča gostoto toka. Ko sprememba potenciala doseže neko stabilno vrednost, potencial kovine postopno naraste zaradi vpliva pasivacije in hitrost pasivacije je najbolj pomemben faktor na začetku pasivacije pri majhni hitrosti pretoka.

Ključne besede: dvofazni tok kapljevina-trdno, elektrokemijske lastnosti, pasivni film, repasivacija

\section{INTRODUCTION}

Stainless steel usually has the ability to resist flowmedia corrosion due to its passive behavior. However, if the passive films are ruptured by the fluid shear stress or solid-particle impacts, fresh metal will be exposed to corrosive media, which may lead to potential and current-density variations. This phenomenon is usually called erosion-enhanced corrosion. ${ }^{1}$

The dissolution and passivation of passive films coexist in the electrochemical reaction system of the metal surface. Once the passive films are ruptured, which is called "the additive", ${ }^{2}$ the dissolution reaction will take place as the dominate process. In this case, the passivated atoms on the metal surface continuously oxidize and form an oxide film to resist the corrosion reaction. This process includes the oxygen mass transfer from the main flow region to the metal surface, ${ }^{3}$ migrations of electrons in the films ${ }^{4}$ and the oxidization of the Fe-alloy. ${ }^{5}$ Some researchers defined the repassivation kinetics, which was determined with the anodic-current density, to indicate the growth of passive films. ${ }^{6}$ The repassivation kinetics was measured with several experimental methods such as the particle-impact test, ${ }^{7,8}$ fracture test ${ }^{9}$ slower electrode straining ${ }^{10}$ and scratching test. ${ }^{11}$ The common difficulties in these measurement processes were the control of the film rupture and the monitoring of the repassivation. This specifically involves obtaining the impact velocity, angle and oxygen concentration near the surface under the flow condition. In addition, particle impacts may cause the open-circuit potential of stainless steel to increase with time until it attains the pitting potential. ${ }^{12}$

In this work, the dissolution and passivation of stainless-steel surface are controlled with a quantitative particle injection. The current density and the open-circuit potential are monitored before and after the injection of particles at different flow velocities. Moreover, the polarization potential, polarization current density and surface morphology are also obtained to investigate the effect of particle impact on the stainless-steel corrosion 
resistance. Finally, the effect of particle impact on the passivation rate is discussed in detail.

\section{EXPERIMENTAL PART}

Electrochemical-corrosion-resistance tests were performed using a solid-liquid two-phase jet-flow system. Unlike in the previous research, ${ }^{7,8,11,12}$ experimental particles were collected with a rectangle box after the particles impacted the sample surface. This could ensure that most particles impacted the specimen only once in each particle injection and that we could control the specific particle impact time.

\subsection{Jet-flow system}

The jet-flow system consisted of a stainless-steel tank, a centrifugal pump, a temperature sensor and a pressure sensor, a magnetic flowmeter (8712HR, Rosemount. Co., America) and a jet test section (Figure 1). Electrochemical measurements were operated using the jet tester as shown in Figure 2. An experimental nozzle (length: $200 \mathrm{~mm}$, inner diameter: $10 \mathrm{~mm}$ ) was used at an impact angle of $90^{\circ}$ (normal incidence) and the jet-flow velocity was changed from $3 \mathrm{~m} / \mathrm{s}$ to $9 \mathrm{~m} / \mathrm{s}$. A three-electrode system was incorporated into a slurry erosion rig for the open-circuit potential and potentiostatic testing. The saturated calomel reference electrode (SCE), placed in the test chamber, was connected to the standard threeelectrode system. A long platinum wire was used as the counter electrode (CE). During the monitoring, the polarization curves were recorded by changing the electrode potential at a sweep rate of $0.2 \mathrm{mV} / \mathrm{s}$. The sample surfaces were examined with scanning electron microscopy (SEM) and an energy dispersive spectrometer (EDS) (JSM-6390). (JSM-6390, JEOL. Co., Japan).

\subsection{Experimental set-up}

The chemical composition of the super $13 \mathrm{Cr}$ stainless steel, used in this experiment, is given in Table $\mathbf{1}$, and the sample with dimensions of $20 \mathrm{~mm} \times 20 \mathrm{~mm}$ and a thickness of $5 \mathrm{~mm}$ is shown in Figure 2. Firstly, each specimen surface was encased in a polymethyl methacrylate (PMMA) insulating sheet, except the test surface.

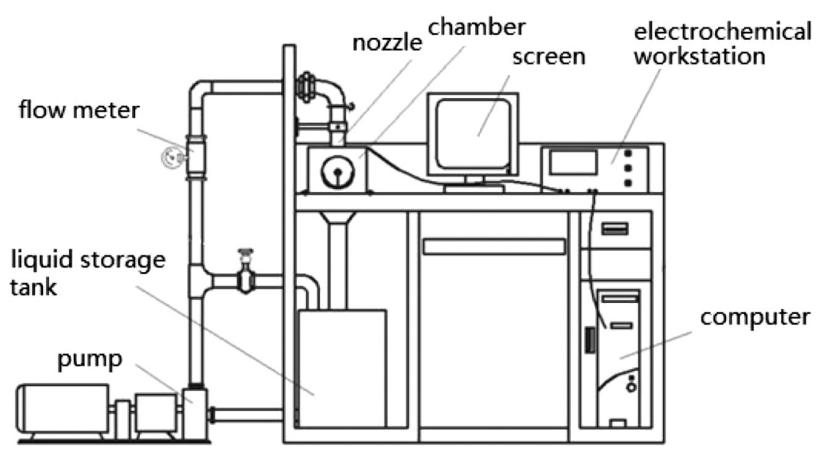

Figure 1: Jet-flow system used in electrochemical experiments

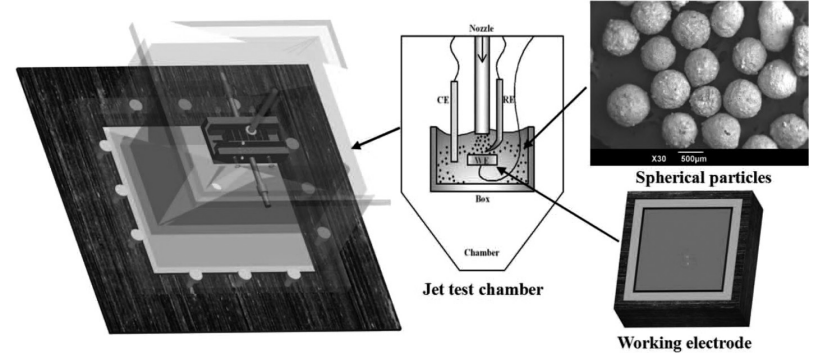

Figure 2: Jet test chamber, electrode arrangement and particle morphology used in the experiments

Secondly, the exposed surface was sealed with epoxy resin and ground using SiC emery paper of grade 1200. The test particles were made of bauxite, and their geometric properties are shown in Table 2. A slurry electrolyte solution of $3.5 \%$ of mass fraction of sodium chloride $(\mathrm{NaCl})$ in double distilled water was used as the circulation media. At the beginning of the experiment, the pump was started and the frequency converter was controlled until the flow-rate fluctuation was less than $0.01 \mathrm{~m}^{3} / \mathrm{h}$. After that, the electrochemical workstation (PARSTAT-2273, Princeton. Co., America) was used to monitor the current and potential. A group of particles (about $75 \pm 0.05 \mathrm{~g}$, amounting to the number of $187500 \pm 125)$ was injected into the tank when the electrochemical system was stable.

Table 1: Chemical composition of the super $13 \mathrm{Cr}$ stainless steel used in the experiment

\begin{tabular}{|c|c|c|c|c|c|c|c|c|}
\hline $\begin{array}{c}\text { Composi- } \\
\text { tion }(w / \%)\end{array}$ & $\mathrm{C}$ & $\mathrm{Cr}$ & $\mathrm{Mo}$ & $\mathrm{Ni}$ & $\mathrm{Si}$ & $\mathrm{Mn}$ & $\mathrm{S}$ & $\mathrm{P}$ \\
\hline Super $13 \mathrm{Cr}$ & 0.022 & 13.22 & 0.94 & 4.81 & 0.26 & 0.45 & 0.0006 & 0.017 \\
\hline
\end{tabular}

Table 2: Parameters of the particles used in erosion testing

\begin{tabular}{|c|c|c|c|}
\hline Parameter & $\begin{array}{c}\text { Diameter } \\
(\mathrm{mm})\end{array}$ & $\begin{array}{c}\text { Mass } \\
(\mathrm{mg})\end{array}$ & $\begin{array}{c}\text { Quantity } \\
(\mathrm{n})\end{array}$ \\
\hline Value & $0.6 \pm 0.03$ & $0.4 \pm 0.05$ & $187500 \pm 125$ \\
\hline
\end{tabular}

\section{RESULTS}

The growth and rupture of passive films occurred simultaneously on the metal surface, and there was a

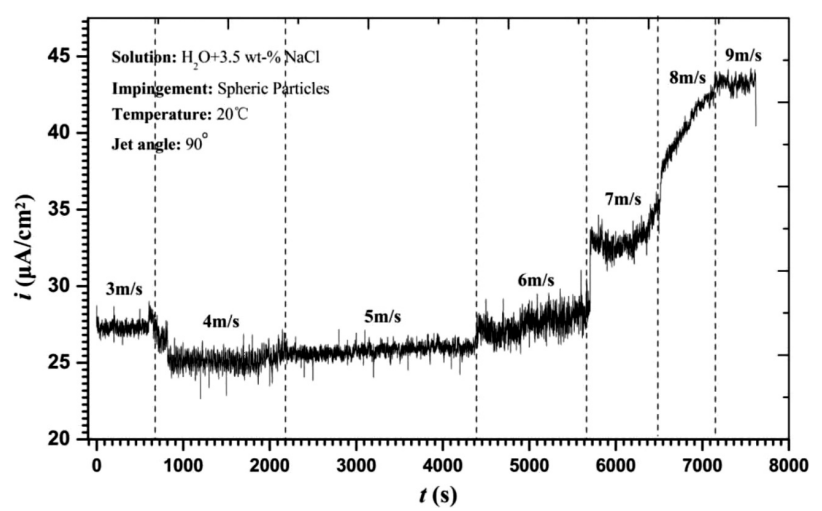

Figure 3: Records of the corrosion current density in response to the changes in the flow velocity at $0 \mathrm{~V}$ vs. SCE 
balanced relation between them in the flow condition. According to the results of Z. B. Zheng's research, ${ }^{13}$ there is a large difference between depassivation and repassivation in a sand-containing $\mathrm{NaCl}$ solution when the flow velocity is below or greater than the critical velocity. In this work, the responding current densities of super $13 \mathrm{Cr}$ stainless steel are presented in Figure 3. The critical velocity that separates the regions of non-observable and significant responses was $7 \mathrm{~m} / \mathrm{s}$. Therefore, the open-circuit-potential monitoring and the polarization measurement were characterized at velocities of $(3,6$ and 9$) \mathrm{m} / \mathrm{s}$ in order to study the depassivation and repassivation of stainless steel in different electrochemical response ranges.

\subsection{Monitoring of the open-circuit potential and cur- rent density}

Figure 4 shows that the OCP changes with the test time at different flow velocities during two particle injections. There are three obvious regimes, including the passive-film formation (Regime I), the breakdown (Regime II) and the recovery (Regime III) during an injection process.

In Regime I (Figure 5), each potential spike shows a rapid fall, followed by a relatively slow exponential rise back to the base line due to the pits persistently growing and metal passivation. The potential increases slowly after a few minutes and shows a small fluctuation. At this moment, metastable pits can initiate and propagate if the potential is below the pitting potential. For example, the OCP changes in a tight range between $-0.20 \mathrm{~V}$ and $-0.02 \mathrm{~V}(\mathrm{SCE})$ at the velocity of $9 \mathrm{~m} / \mathrm{s}$, and then it gradually steadies at $-0.17 \mathrm{~V}$ (SCE).

In Regime II (Figure 6), the value of the OCP changes in the negative direction when particles are injected into the jet-flow system. Part of the passive films ruptures immediately and forms slowly after the particle impact in a few seconds. It causes the potential to change negatively from $-0.165 \mathrm{~V}$ to $-0.57 \mathrm{~V}$ $(v=9 \mathrm{~m} / \mathrm{s})$ and the current density to increase from $28 \mu \mathrm{A}$ to $57 \mu \mathrm{A}$. In this process, the decrease in the OCP and the increase in the current density are changed

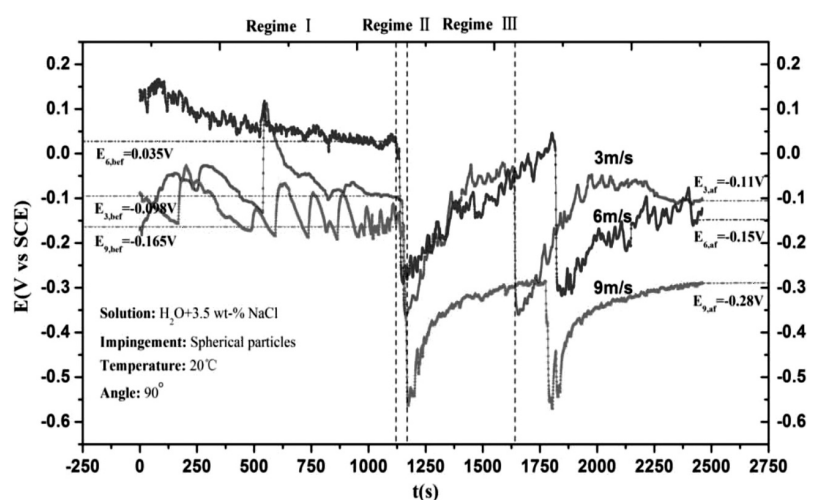

Figure 4: Open-circuit potentials under the solid-liquid jet flow at the velocities of $(3,6$ and 9$) \mathrm{m} / \mathrm{s}$, respectively

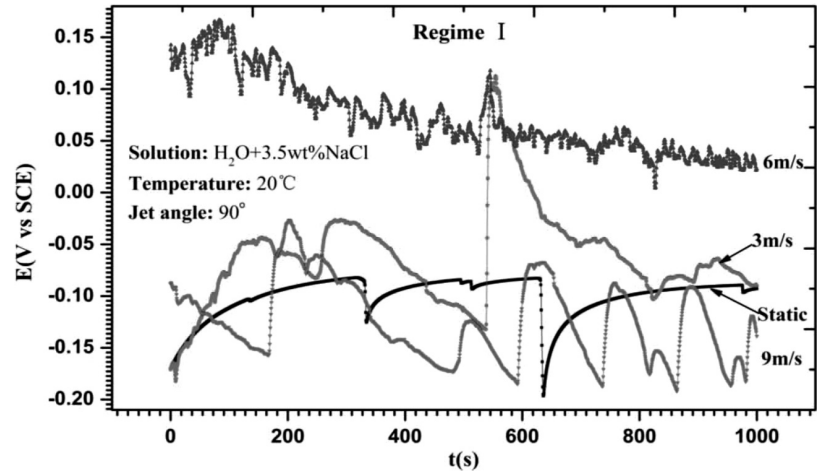

Figure 5: Open-circuit potentials of super $13 \mathrm{Cr}$ stainless steel under the jet flow free of particles

nonlinearly because of the nonlinear growth of fresh areas. Moreover, when the particles stop to impact the metal surface, the flow system and electrochemical system need a certain period of time to become stable. The OCP increases slowly, with a slight concussion, to $-0.29 \mathrm{~V}$ (SCE) in a single-phase flow, containing $3.5 \%$ mass fractions of $\mathrm{NaCl}$. The difference between the potential values before and after the particle impacts is equal to $0.12 \mathrm{~V}$ (SCE).

After that, the particles are injected into the system again with the aim to confirm that the behavior of the breakdown and recovery of a passive film is repeatable. The minimum values of the OCP in the process of the first and second particle injection are very close. Therefore, when the potential goes below a certain value, the potential will no longer decrease obviously. In addition, after the metal-surface passivation, the stable potential is generally lower than the initial potential before the injection of particles. Thus, the corrosion resistance of the repassivated film is not as strong as before because electrode potential deviates negatively from equilibrium potential.

\subsection{Polarization measurement}

A polarization-curve test was used to compare the current densities and potentials before and after the

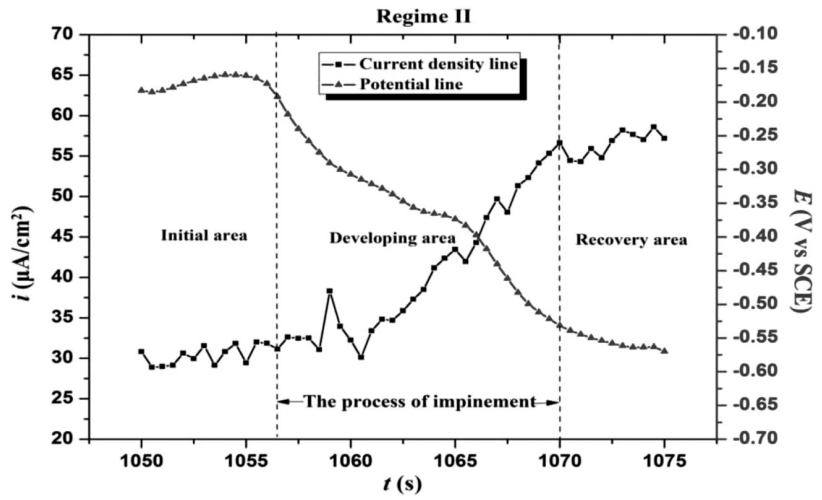

Figure 6: Records of open-circuit potential and current density in response to particle impingement at the velocity of $9 \mathrm{~m} / \mathrm{s}$ : a) single-phase solution, b) solid-liquid two-phase solution 

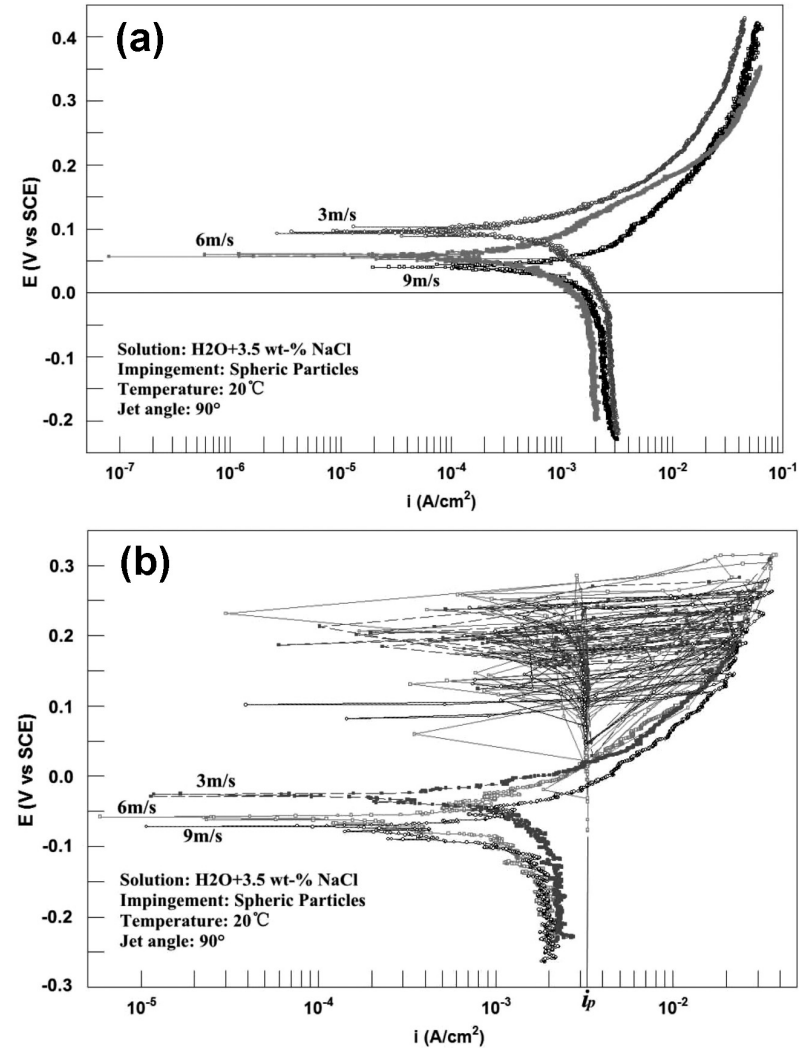

Figure 7: Polarization curves for super $13 \mathrm{Cr}$ stainless steel in the flowing condition

particles impacted the sample. Figure 7a shows the polarization curves for super $13 \mathrm{Cr}$ stainless steel at different flow velocities in a single-phase solution. When the flow velocity is increased from $3 \mathrm{~m} / \mathrm{s}$ to $9 \mathrm{~m} / \mathrm{s}$, the anodic polarization curves move towards the negative direction, and there is no obvious passivation region of each anode polarization curve. The corrosion potential $E_{\text {corr }}$ at the flow velocity of $9 \mathrm{~m} / \mathrm{s}$ is slightly lower than at $3 \mathrm{~m} / \mathrm{s}$ and $6 \mathrm{~m} / \mathrm{s}$. And the anodic dissolution current at a higher anodic potential at the flow velocity of $3 \mathrm{~m} / \mathrm{s}$ is even lower than that at $6 \mathrm{~m} / \mathrm{s}$. In addition, the metastable pitting activity can be seen at the velocity of $3 \mathrm{~m} / \mathrm{s}$ as revealed by a series of transients from $0.68 \mathrm{~V}$ to $0.85 \mathrm{~V}$.

The polarization curves at different flow velocities under particle impingement are presented in Figure 7b. Like the polarization curves in the single-phase solution, they show no obvious passivation region of each anode

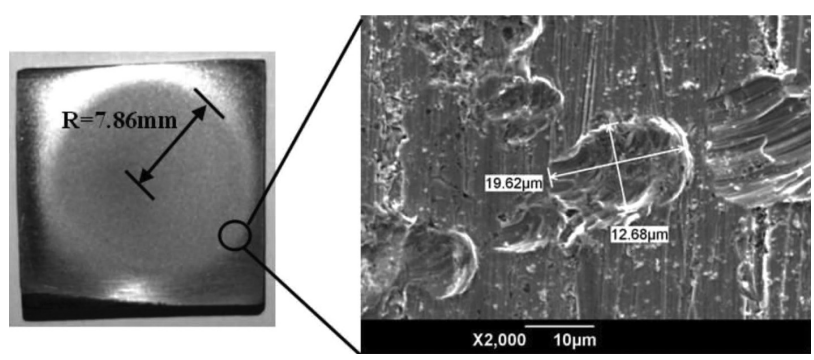

Figure 8: Erosion surface morphology on the outer circumference surface polarization curve. However, anodic polarization causes violent fluctuations at the velocities of 6 and $9 \mathrm{~m} / \mathrm{s}$. The anodic current densities change in the range of 7.3-64.7 $\mathrm{mA}$ for the jet velocity of $6 \mathrm{~m} / \mathrm{s}$ and $6.9-48.4 \mathrm{~mA}$ for the jet velocity of $9 \mathrm{~m} / \mathrm{s}$. The passivation current density varies continuously and tends toward a relatively stable value of $i_{\mathrm{p}}$. Meanwhile, this current density $i_{\mathrm{p}}$ at the velocity of $6 \mathrm{~m} / \mathrm{s}$ is close to that at $9 \mathrm{~m} / \mathrm{s}$, which indicates that the fluctuation of $i_{\mathrm{p}}$ is more affected by particle impingement than the flow velocity.

\subsection{Surface morphology}

A typical particle impact crater on a sample surface is shown in Figure 8. The outer-circumference area suffers from an occasional impact of a few particles, and it has no uniform thinning of the surface. The center area of the sample is subjected to repeated particle impacts and has craters, platelets and extruding lips on the surface, as shown in Figure 9a. For the sake of contrast, the surface of the same sample after $1 \mathrm{~h}$ of exposure to the singlephase flow containing $3.5 \%$ of mass fractions of $\mathrm{NaCl}$ at $9 \mathrm{~m} / \mathrm{s}$ is revealed in Figure 9b. Numerous, a few $\mu \mathrm{m}$ wide, lips or platelets are not obvious; they are the result of mechanical cutting or corrosion. The convex parts around the craters are worn by the fluid shear stress and, consequently, more chloride ions make incursions into material's body. In fact, a pit of around $17.5 \mu \mathrm{m}$ (Figure 10) in width is found on the sample immersed in the
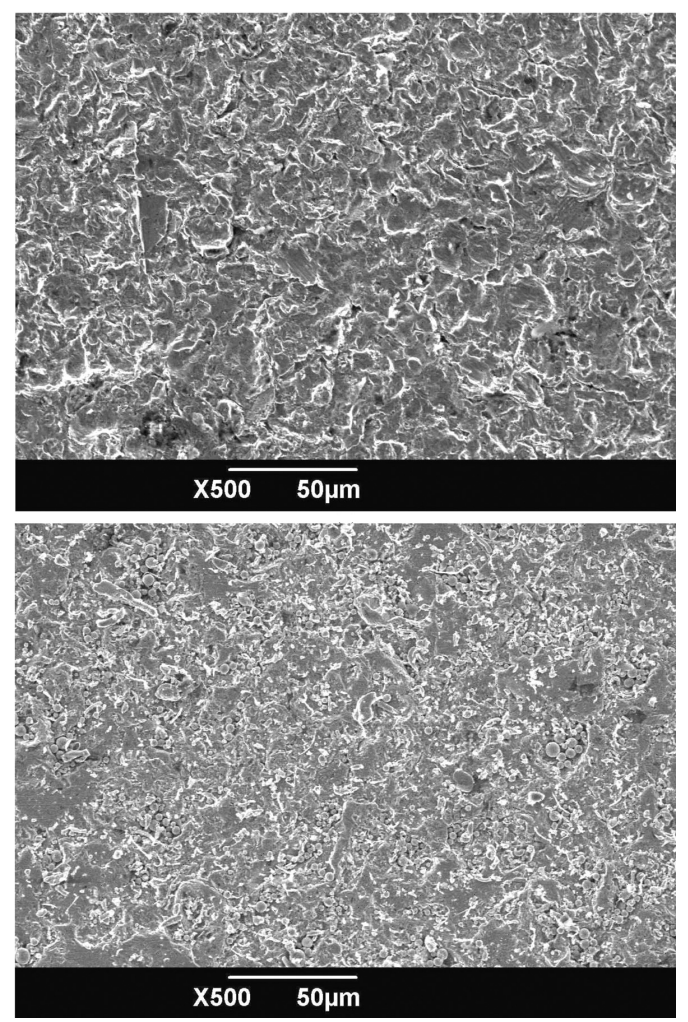

Figure 9: SEM micrographs of the erosion surface of super $13 \mathrm{Cr}$ stainless steel at the jet velocity of $9 \mathrm{~m} / \mathrm{s}$ : a) surface topography after particle impact, b) erosion surface morphology after corrosion 


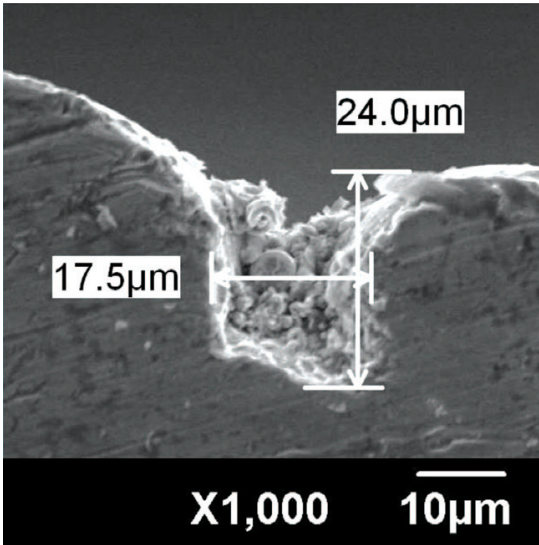

Figure 10: SEM view of defects formed on the erosion surface immersed for $1 \mathrm{~h}$ in a $3.5 \%$ of mass fraction of $\mathrm{NaCl}$ solution

$\mathrm{NaCl}$ solution, which is larger than the ones reported in M. Finšgar and I. Milošev's research ${ }^{14}$ (pits of around 2.5 $\mu \mathrm{m}$ in width). It is confirmed that the anti-pitting ability is weakened by particle impingement, which makes the metal surface not smooth in the flow condition. To assess the chemical composition of the erosion surface before and after corrosion, EDS was performed on the same area of the center surface (Figure 11). The oxygen peak is presented as oxidation while iron and chromium are present in both the metallic and oxide states, and
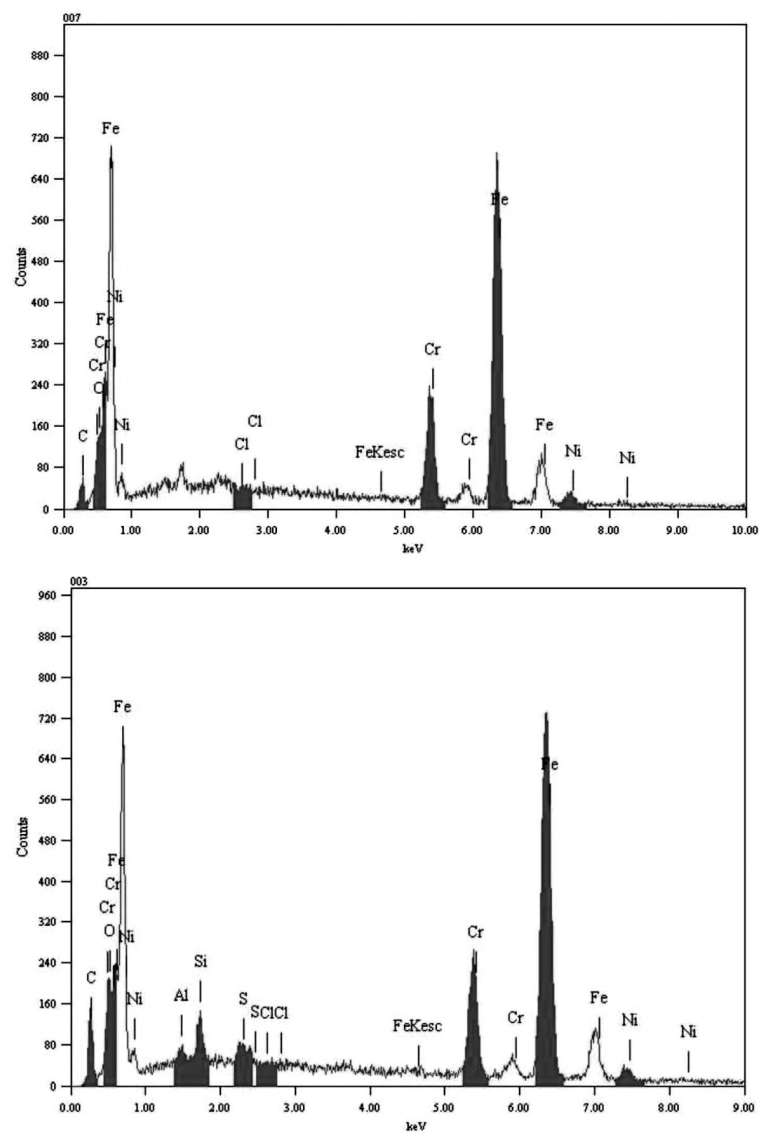

Figure 11: EDS analysis of the chemical composition of the stainless-steel surface after: a) particle impact and b) corrosion chlorine slightly increases after the passivation for $1 \mathrm{~h}$. Hence, there is a loose surface of the metal, caused by the impact of particles, which is more susceptible to chloride ion corrosion.

\section{DISCUSSION}

As shown in Figure 4, the surface potential impacted by the particles will not be reduced indefinitely, but there is a minimum value. In this work, the number of particles that flow out of the nozzle every second is more than 5000, which leads to the passive time of the unit erosion area being less than $0.05 \mathrm{~s}$. Most of the passive films, therefore, are ruptured by the persistent impact of particles until the exposed areas tend not to change. We use the change in the potential in such a way that it reflects the passivation characteristics of the surface during particle impacting and after particle impacting. According to the point defect model, the voltage drop across the film/solution interface is defined with Equation (1): ${ }^{15}$

$$
\Delta E=E_{0}+\alpha E_{1}+\beta p H
$$

where $E_{0}$ is the zero voltage drop, $\alpha$ is the polarizability of the film/solution interface, and $\beta$ is the dependence of the voltage. If the effect of $\mathrm{pH}$ on the voltage drop is not taken into account, a passive fitting equation is obtained in Equation (2):

$$
E=E_{0}+E_{1} \exp \left(-\frac{t}{\tau}\right)
$$

where $\tau$ is the decay constant, $E_{0}$ is the minimum value of the OCP during the particle impact on the metal surface, and $t$ is the passive time after the particle impingement. According to the experimental data shown in Figure 4, the passivation rate can be indicated by the slope of a OCP curve, called passivation coefficient $\lambda$ in Equation (3):

$$
\lambda=\left|\frac{\Delta E}{\Delta t}\right| \approx\left|\frac{d E}{d t}\right|=\frac{1}{\tau} E_{1} \exp \left(-\frac{t}{\tau}\right)
$$

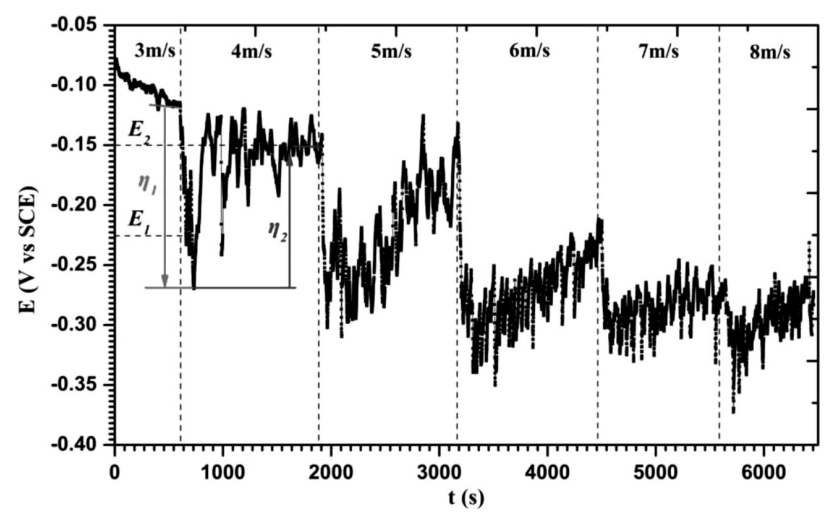

Figure 12: Continuous changes in the potential at different flow velocities 


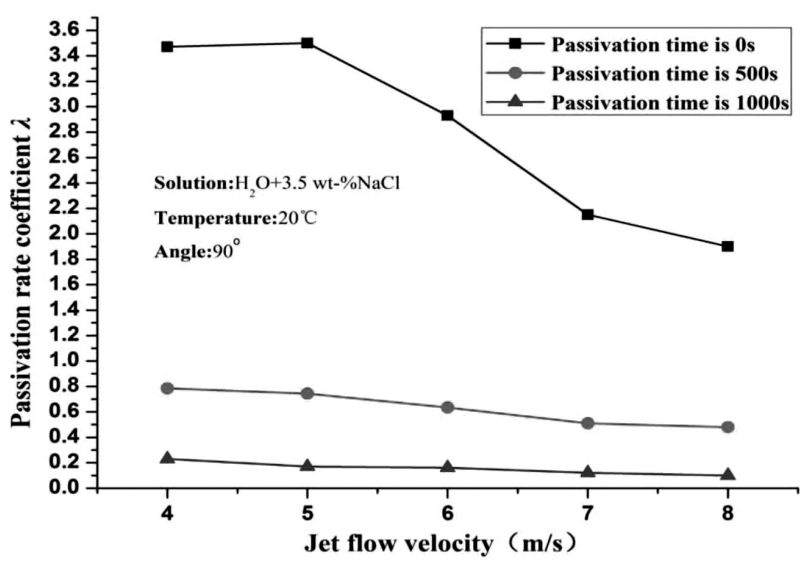

Figure 13: Passivation-rate coefficient versus jet-flow velocity over time

If the collection of particles is cancelled, the particles will impact the sample surface without interruption. At this moment, we get the curves of the potential changes under different flow velocities in the solid-liquid solution (Figure 12). Here, $E_{1}$ and $E_{2}, \eta_{1}$ and $\eta_{2}$ represent the potential at the beginning and the end of the passivation at the same flow velocity, the potential reduction during the changing flow velocity and the increase in the potential during the passivation process. Table $\mathbf{3}$ shows detail values of each parameter. It is found that not only the potential $\left(E_{1}\right.$ and $\left.E_{2}\right)$ but also the change in the potential $\left(\eta_{1}\right.$ and $\left.\eta_{2}\right)$ decrease with the increasing velocity. The decrease in $E_{2}$ indicates that the metal surface is more susceptible to corrosion, and the decrease in $E_{2}$ reflects that the passivation ability of the stainless-steel surface decreases at high flow velocities. Thus, the rule, according to which the coefficient decreases with the increasing two-phase flow velocity, is obtained. However, the effect of the increasing velocity on the reduction of the potential is not always significant, as it may weaken when the flow velocity increases, which can be seen from the change in $\eta_{1}$. The difference in the potential for the flow velocities of $7 \mathrm{~m} / \mathrm{s}$ and $8 \mathrm{~m} / \mathrm{s}$ is close to $0.04 \mathrm{~V}$, which is much smaller than the potential absolute value.

Table 3: Values of passivation parameters in potential monitoring (the test time for each flow velocity is $1200 \mathrm{~s}$ )

\begin{tabular}{|c|c|c|c|c|c|}
\hline \multirow{2}{*}{$\begin{array}{c}\text { Jet-flow } \\
\text { velocity } \\
(\mathrm{m} / \mathrm{s})\end{array}$} & \multirow{2}{*}{ Potential } & $\begin{array}{c}\text { Potential } \\
\text { difference }\end{array}$ & \multicolumn{3}{|c|}{ Passivation coefficient } \\
\cline { 2 - 6 } & $E_{1} / \mathrm{V}$ & $E_{2} / \mathrm{V}$ & $\eta_{1} / \mathrm{V}$ & $\eta_{2} / \mathrm{V}$ & $\lambda$ \\
\hline 3 & - & -0.12 & - & - & - \\
\hline 4 & -0.23 & -0.15 & 0.11 & 0.08 & 1.33 \\
\hline 5 & -0.27 & -0.17 & 0.12 & 0.10 & 1.67 \\
\hline 6 & -0.28 & -0.24 & 0.11 & 0.04 & 0.67 \\
\hline 7 & -0.31 & -0.28 & 0.07 & 0.03 & 0.50 \\
\hline 8 & -0.32 & -0.28 & 0.04 & 0.04 & 0.67 \\
\hline
\end{tabular}

If the particles are collected after impacting the sample, the passivation coefficient can be obtained by fitting the potential curves for the single-phase flow.
According to the passivation curves (Figure 4), the decay constant $\tau$ changes in the negative direction with the increasing jet-flow velocity, as shown in Table 4. The smaller decay constant $\tau$ refers to the passivation coefficient $\lambda$ decreasing over the time, which means that the passivation reaction is more difficult to obtain at high flow velocities. As shown in Figure 13, the passivation coefficient has the maximum value at the beginning of passivation, which decreases remarkably as time goes on. When $\lambda$ is less than 0.01, the increase in the OCP is also less than $0.01 \mathrm{~V}$ in every second. At this time, the passive reaction and the active reaction can be considered to be balanced. However, the final OCP after the passivation is lower than the initial result before the particle impact, which may be caused by a high vertical particle impact.

Table 4: Parameters of two fitting curves at different flow velocities

\begin{tabular}{|c|c|c|c|c|}
\hline \multirow{2}{*}{$\begin{array}{c}\text { Velocity } \\
(\mathrm{m} / \mathrm{s})\end{array}$} & \multicolumn{2}{|c|}{ First passivation } & \multicolumn{2}{c|}{ Second passivation } \\
\cline { 2 - 5 } & $E_{1}(\mathrm{~V})$ & $\tau$ & $E_{1}(\mathrm{~V})$ & $\tau$ \\
\hline 3 & 3.9 & 2.3 & 4.7 & 3.5 \\
\hline 6 & 2.7 & 1.8 & 3.3 & 1.8 \\
\hline 9 & 1.9 & 0.8 & 1.2 & 0.9 \\
\hline
\end{tabular}

\section{CONCLUSIONS}

A solid-liquid-jet-flow experiment was carried out to evaluate the effect of particle impingement on the electrochemical characterization of super $13 \mathrm{Cr}$ stainless steel at different flow velocities. At the macroscopic level, the open-circuit potential changes non-linearly in the negative direction and the current density changes in the positive direction in the solid-liquid two-phase flow. The OCP at the end of the passivation is lower than before the particle impacts. This indicates that particle impacts can weaken the corrosion resistance of stainless steel in the chloride medium. However, there is a limit to this weakening effect. For example, in the process of multiple impacts at the same velocity, the minimum potentials are the same at each particle impact. Meanwhile, the decrease in the potential gradually stabilizes with the increasing flow velocity. Beyond this, the higher the impact velocity of particles, the lower is the passivation coefficient per unit of time. At the same time, the passivation coefficient reaches the maximum value and then drops with the increasing time. In addition, at the microscopic level, the impact of each small particle has an impact on the metal-surface properties.

This effect mainly reflects the following aspects: First, anodic polarization is constantly disturbed by particle impacts between the activated state and the passive state. Second, pitting corrosion is caused by tiny ions that more easily penetrate into the loose oxide layer. 


\section{Acknowledgement}

This work was supported by the National Natural Science Foundation of China (grant no. 51674199), and it was also performed by The Research Institute of Safety Evaluation and Control of Completion Test System.

\section{REFERENCES}

${ }^{1}$ L. Zeng, G. A. Zhang, X. P. Guo, Erosion-corrosion at different locations of X65 carbon steel elbow, Corros. Sci., 85 (2014) 4, 318-330, doi:10.1016/j.corsci.2014.04.045

${ }^{2}$ M. M. Stack, N. Corlett, S. Turgoose, Some thoughts on modelling the effects of oxygen and particle concentration on the erosion-corrosion of steels in aqueous slurries, Wear, 255 (2003) 1, 225-236, doi:10.1016/S0043-1648(03)00205-9

${ }^{3}$ H. Martin, Heat and mass transfer between impinging gas jets and solid surfaces, Int. J. Therma. Sci., 13 (1977), 1-60, doi:10.1016/ S0065-2717(08)70221-1

${ }^{4}$ A. Alamr, D. F. Bahr, M. Jacroux, Effects of alloy and solution chemistry on the fracture of passive films on austenitic stainless steel, Corros. Sci., 48 (2006) 4, 925-936, doi:10.1016/j.corsci.2005.02.018

${ }^{5}$ D. H. Kang, H. W. Lee, Study of the correlation between pitting corrosion and the component ratio of the dual phase in duplex stainless steel welds, Corros. Sci., 74 (2013) 4, 396-407, doi:10.1016/j.corsci.2013.04.033

${ }^{6}$ T. Yamamoto, K. Fushimi, M. Seo et al., Depassivation-repassivation behavior of type-312L stainless steel in $\mathrm{NaCl}$ solution investigated by the micro-indentation, Corros. Sci., 51 (2009) 7, 1545-1553, doi:10.1016/j.corsci.2008.11.020
${ }^{7}$ B. T. Lu, J. L. Luo, F. Mohammadi et al., Correlation between repassivation kinetics and corrosion rate over a passive surface in flowing slurry, Electrochim. Acta, 53 (2008) 23, 7022-7031, doi:10.1016/j.electacta.2008.02.083

${ }^{8}$ F. Mohammadi, J. Luo, Effects of particle angular velocity and friction force on erosion enhanced corrosion of 304 stainless steel, Corros. Sci., 52 (2010) 9, 2994-3001, doi:10.1016/j.corsci.2010. 05.012

${ }^{9}$ A. Yabuki, Particle-induced damage and subsequent healing of materials: Erosion, corrosion and self-healing coatings, Adv. Powder Technol., 22 (2011) 3, 303-310, doi:10.1016/j.apt.2010.10.016

${ }^{10}$ F. M. Song, K. S. Raja, D. A. Jones, A film repassivation kinetic model for potential-controlled slower electrode straining, Corros. Sci., 48 (2006) 2, 285-307, doi:10.1016/j.corsci.2005.02.001

${ }^{11}$ X. Ji, J. Zhao, X. Zhang et al., Erosion-corrosion behavior of Zr-based bulk metallic glass in saline-sand slurry, Tribol. Int., 60 (2013) 7, 19-24, doi:10.1016/j.triboint.2012.10.010

${ }^{12}$ K. Sasaki, G. T. Burstein, Erosion-corrosion of stainless steel under impingement by a fluid jet, Corros. Sci., 49 (2007) 1, 92-102, doi:10.1016/j.corsci.2006.05.012

${ }^{13}$ Z. B. Zheng, Y. G. Zheng, X. Zhou et al., Determination of the critical flow velocities for erosion-corrosion of passive materials under impingement by $\mathrm{NaCl}$ solution containing sand, Corros. Sci., 88 (2014) 16, 187-196, doi:10.1016/j.corsci.2014.07.043

${ }^{14}$ M. Finšgar, I. Milošev, Corrosion behaviour of stainless steels in aqueous solutions of methanesulfonic acid, Corros. Sci., 52 (2010) 7 , 2430-2438, doi:10.1016/j.corsci.2010.04.001

${ }^{15}$ D. D. Macdonald, The history of the Point Defect Model for the passive state: A brief review of film growth aspects, Electrochim. Acta, 56 (2011) 4, 1761-1772, doi:10.1016/j.electacta.2010.11.005 